Association for Information Systems AIS Electronic Library (AISeL)

AMCIS 2001 Proceedings

Americas Conference on Information Systems

(AMCIS)

December 2001

\title{
Bullying on the Net: Adverse Behavior on the E- Mail and Its Impact
}

Yehuda Baruch

University of East Anglia

Follow this and additional works at: http://aisel.aisnet.org/amcis2001

\section{Recommended Citation}

Baruch, Yehuda, "Bullying on the Net: Adverse Behavior on the E-Mail and Its Impact" (2001). AMCIS 2001 Proceedings. 97. http://aisel.aisnet.org/amcis2001/97

This material is brought to you by the Americas Conference on Information Systems (AMCIS) at AIS Electronic Library (AISeL). It has been accepted for inclusion in AMCIS 2001 Proceedings by an authorized administrator of AIS Electronic Library (AISeL). For more information, please contact elibrary@aisnet.org. 


\title{
BULLYING ON THE NET: ADVERSE BEHAVIOR ON THE E-MAIL AND ITS IMPACT
}

\author{
Yehuda Baruch \\ University of East Anglia \\ y.baruch@uea.ac.uk
}

\begin{abstract}
A study into the effects of bullying at work, including bullying via e-mail, was conducted in a large Multi National Corporation. A considerable amount of bullying was found on the e-mail system, with negative outcomes similar to those of conventional bullying. Bullying was associated with anxiety and tendency to quit, and negatively associated with job satisfaction and performance. The results expand current understanding of the drawbacks associated with misuse and abuse of information technology in an organizational context.
\end{abstract}

\section{Information Technology, Communication and Organizations}

The electronic network, and in particular the e-mail media, form technology tools which enables a fast, accurate and effective means of communication. Moreover, the utilization of e-mail systems has far reaching outcomes; perhaps even more than it was designed to achieve. This paper will focus on a negative side effect of e-mail system - misuse and abuse of the system via bullying and will explore the extent and possible impact of the use of e-mail systems for bullying in the workplace.

\section{Theoretical Model Development}

The theoretical base for understanding adverse behavior in organizations and its outcomes can be traced back to Gouldner's (1960) classic article about norms of reciprocity. Bullying is a form of verbal aggressive behavior. In addition to accidental cases, certain people may intentionally use malicious or defamatory messages to bully others. Vardi \& Winer 1996 'misbehavior in organizations' and Anderson and Pearson, 1999, 'mistreatment in organizations' may act here as a cover framework

\section{E-Mail}

E-mail is a recent, different type of communication system, a cost-effective, user friendly internal and external information system, which speedily spread in organizations. e-mail may be placed in the middle range on the dimension of richness, complexity and formality. It is easily accessed, enables a quick response, but also allows an unsynchronized two-way conversation. These features can cause communication problems in office related environment (Joseph, 1998). With no face-to-face interactions there is neither the tone of the spoken word, nor eye contact. Sproull and Kiesler (1986) have already pointed out the risks of misunderstanding and distortion of messages' meaning, following lack of social context cues in e-mail communication.

E-mail history of communication can be kept and be retrieved. Thus it can serve as formal evidence to prove indecent or incorrect approaches, unethical or impolite manners, use of improper language, and bullying. This in itself should deter the sensible sender from using this medium for bullying and other malicious practice. However, lack of awareness, and the above mentioned option of immediacy in response might end with undesired consequences, one of them could be bullying. Thus, there is a need to explore its full impact on other facets of organizational life.

Hypothesis 1. Bullying will be apparent on the e-mail system, at a level similar to other methods used for bullying 


\section{Bullying at Work}

Bullying in the workplace is considered a great obstacle for individual and organizational effectiveness. It is perceived to cause a high level of anxiety and stress, which subsequently leads to low performance and high turnover amongst employees at all levels. Bullying is a clear manifestation of violence in the workplace (Neuman \& Baron, 1998) and workplace incivility (Anderson $\&$ Pearson, 1999), which is gaining attention in recent literature due to its adverse impact on people and organizations (Pearson, Anderson \& Porath, 2000).

The issue of workplace bullying has gained a lot of attention in media and academic circles, including involvement of the legal procedures for treating cases of bullying. Also flame e-mail could cause an increase in stress related illness and harassment (Welch, 1997). Misuse and even abuse of the system such as using e-mail communication for bullying is a real life phenomenon, as suggested by Novell (1998). Bullying could be a direct result of daily pressures people experience in today's stressful life. However, the adverse results of bullying are not expected to be subject to the system that carries the message.

Hypothesis 2. Negative outcomes of bullying will exist irrespectively to the media of communication.

\section{The Impact of Bullying on Job Attitudes, Emotions and Behaviors}

Bullying is a highly negative behavior, and similarly to the prospect impact of other adverse behaviors, its existence will result in negative impact on people attitudes and behaviors in organizations.

The negative impact of adverse behavior is not restricted to attitudes, and another human response is manifested through emotional reaction. Office politics provide a vivid example of exploitation and abuse of emotions in work environment. Clarke (1999) suggests a framework that distinguishes between the kind of motives and the level of competence (in organizational politics). Email abuse may follow negative motives, and may come from people of varied level of competence and status. The office, once considered hazard-free in relation to health and safety, is increasingly losing its reputation (Mogensen, 1996), with stress related issues such as bullying held responsible for the shift. Fisher and Ashkanasy emphasized the expected impact on performance, satisfaction, commitment, well-being, stress and health.

Many theoretical frameworks as well as empirical studies pointed the anticipated effects of stress and anxiety on performance (cf. Bhagat, 1983). Stress leads to anxiety, which describes the effect of combined emotional negative affect and physiological arousal (Freud, 1926). Anxiety can be a response to an actual situation, or related to a perceived threat. Anxiety therefore is not a simple, unidimensional concept, but one that "may involve complex chains of behaviour and vicious cycle phenomena" (Hallam, 1992).

Hypothesis 3. Bullying in general and bullying on the e-mail in particular will have a negative impact on job satisfaction, performance, anxiety, absenteeism, and tendency to quit.

\section{Method}

\section{Sample}

A questionnaire was sent as an attachment to e-mail message, which was conveyed to the e-mail users of the UK subsidiary in a large Multi National Corporation (the vast majority of the company's office-based workforce, including managers, professional and support staff). Altogether the list included some 1600 employees. A reminder message followed two weeks later. An option enabled those interested to respond through regular mail or fax, due to the sensitivity of the subject.

Instruments included a set of single item measures for the following research variables: job satisfaction, performance, anxiety, absenteeism, and tendency to quit. They were also asked if they have experienced bullying at work, and if so, was it conveyed via the e-mail system. Six hundred and forty nine participants replied, representing a response rate of 43.6. Those who had experienced bullying via the e-mail were asked to respond in addition to a wider set of questions, including already validated measures, using multiple item questions. Sixty of them did so, plus 19 of those bullied via other means (all in all, 79 sub-sample). 


\section{Results}

Frequency of general bullying in the company was similar to that experienced in the UK - of the 649 respondents 501 (77.2\%) reported that they have never experienced it. The remainder were $88(13.6 \%)$ who experienced bullying but not via e-mail, and $60(9.2 \%)$ who experienced it also on e-mail. Out of those bullied, 54 did not perceive themselves to respond similarly, but 22 admitted that they were bullying others, usually as a response (as claimed in most cases). See Table 1a-c for the media and frequency of bullying, and the type and source of bullying on e-mail, and personal characteristics of population.

Table 1a. Media and Frequency of Bullying

\begin{tabular}{|l|c|c|c|c|c|c|}
\hline & $\begin{array}{c}\text { only } \\
\text { once }\end{array}$ & $\begin{array}{c}\text { about once } \\
\text { a year }\end{array}$ & $\begin{array}{c}\text { about once } \\
\text { a month }\end{array}$ & $\begin{array}{c}\text { about once } \\
\text { a week }\end{array}$ & $\begin{array}{c}\text { about once a } \\
\text { day }\end{array}$ & $\begin{array}{c}\text { more than } \\
\text { once a day }\end{array}$ \\
\hline face-to face & 21 & 21 & 40 & 20 & 14 & 6 \\
\hline meeting(s) & 21 & 18 & 20 & 16 & 3 & - \\
\hline letters/memos & 5 & 14 & 15 & 4 & 1 & - \\
\hline phone conversation & 10 & 15 & 19 & 16 & 2 & 1 \\
\hline e-mail & 14 & 11 & 23 & 4 & 3 & 1 \\
\hline other (please specify) & 4 & 2 & 2 & 1 & - & 1 \\
\hline
\end{tabular}

Table 1b. Type and Source of Bullying on E-Mail

\begin{tabular}{|l|c|c|c|c|c|c|}
\hline & $\begin{array}{c}\text { direct } \\
\text { manager }\end{array}$ & $\begin{array}{c}\text { higher } \\
\text { level } \\
\text { manager }\end{array}$ & peers & $\begin{array}{c}\text { sub- } \\
\text { ordinates }\end{array}$ & customers & suppliers \\
\hline Insults, work related & 19 & 9 & 18 & 2 & 4 & 1 \\
\hline Insults of a personal nature & 4 & 4 & 4 & 2 & - & - \\
\hline Intimidation & 23 & 10 & 14 & 3 & 4 & 1 \\
\hline Personal threats & 5 & 2 & 3 & 1 & - & - \\
\hline Verbal abuse & 4 & 2 & 8 & - & 1 & - \\
\hline Sexual bullying & 2 & 1 & - & 1 & - & - \\
\hline Others & 3 & - & - & - & - & - \\
\hline
\end{tabular}

Table 1c. Personal Characteristics

\begin{tabular}{|l|l|l|}
\hline & \multicolumn{1}{|c|}{ Respondent } & \multicolumn{1}{c|}{ Alleged bully } \\
\hline gender & \multicolumn{1}{|c|}{51} & \multicolumn{1}{c|}{53} \\
& \multicolumn{1}{|c|}{24} & \multicolumn{1}{c|}{16} \\
\hline Fale & \multicolumn{1}{|c|}{24} & $49.2(22.2)$ \\
\hline age (SD) & $43.2(17.7)$ & White-62 \\
\hline ethnic origin & White-64 & Others-3 \\
& Others-6 & Managerial-36 \\
& Managerial-12 & Supervisory-13 \\
& Supervisory-12 & Professional-10 \\
& Professional-34 & Administrative \& others-5 \\
& Administrative \& others-12 & \multicolumn{1}{c|}{58} \\
\hline \multicolumn{2}{|c|}{57} & 4 \\
\hline
\end{tabular}

The ANOVA analysis presented shows no significant difference, i.e. bullying is bullying, no matter what the media is, and the negative impact has less to do with the media but with the issue itself.

These results fully support the first two Hypotheses. 


\section{Association among the Research Variables}

\section{Single Measure Versus Combined, Validated Multiple Item Measures}

The questionnaire form for people who were bullied included, in addition to the single item measures, a wider set of measures that were already validated in earlier studies. In particular 'job satisfaction' and 'tendency to quit' were 'properly' measured via multiple item measures for 75 participants. The correlation of .60 between the single item measure for job satisfaction and a four items measure for the same variable (Cronbach alpha=.75, N=75), and the correlation of .73 between the single item measure for 'tendency to quit' and a four items measure for the same variable (Cronbach alpha=.89, N=75) strongly support the validity of single item application in this study. Subsequently, the single-item measures were utilized in the study. Table 2 (correlation table) and Table 3 (regression' output) focus on the impact of bullying.

Table 2. Correlation Among Research Variables

\begin{tabular}{|c|c|c|c|c|c|}
\hline & JOBSAT & TTQUIT & ABSENT & ANXIETY & PERFORM \\
\hline TTQUIT & $-.4983 * *$ & & & & \\
\hline ABSENT & -.0680 & $.1944 * *$ & & & \\
\hline ANXIETY & $-.1517 * *$ & $.2417 * *$ & .0162 & & \\
\hline PERFORM & $.2592 * *$ & $-.1128 *$ & -.0624 & $-.0777 \pm$ & \\
\hline TOTBULL & $-.1867 * *$ & $.2600 * *$ & .0566 & $.2301 * *$ & -.0109 \\
\hline
\end{tabular}

N-649; $\mathrm{p}<.000 ; * \mathrm{p}<.01 ; \pm \mathrm{p}<.05 ;$ coefficient / (Cases) / 2-tailed Significance)

Table 3a. Regression (Stepwise) Analysis: Tendency to Quit as a Dependent Variable: Model Summary

\begin{tabular}{|c|c|c|c|c|c|c|c|}
\hline R & R Square & $\begin{array}{c}\text { Adjusted R } \\
\text { Square }\end{array}$ & $\begin{array}{c}\text { Std. Error } \\
\text { of the } \\
\text { Estimate }\end{array}$ & F Change & df1 & df2 & Sig. F \\
\hline & & & & & & & \\
\hline .574 & .329 & .325 & 1.53 & 16.018 & 1 & 611 & .000 \\
\hline
\end{tabular}

Predictors: (Constant), Job Satisfaction, BULLY, absenteeism, ANXIETY

Table 3a: Regression (Stepwise) Analysis: Tendency to Quit as a Dependent Variable: Coefficients

\begin{tabular}{|l|l|c|c|c|r|r|}
\hline & & $\begin{array}{c}\text { Unstandardized } \\
\text { Coefficients }\end{array}$ & & $\begin{array}{c}\text { Standardized } \\
\text { Coefficients }\end{array}$ & \multicolumn{1}{c|}{$\mathbf{t}$} & Sig. \\
\hline Model & & B & Std. Error & Beta & & \\
\hline & (Constant) & 3.962 & .353 & & 11.233 & .000 \\
\hline & Job Satisfaction & -.626 & .049 & -.438 & -12.901 & .000 \\
\hline & BULLY & .509 & .099 & .175 & 5.130 & .000 \\
\hline & absenteeism & .258 & .055 & .157 & 4.721 & .000 \\
\hline & Anxiety & .155 & .039 & .136 & 4.002 & .000 \\
\hline
\end{tabular}

a Dependent Variable: tendency to quit

Bullying Impact on Job Attitudes and Behaviors

To study the possible impact a regression analysis was conducted, and bullying was a significant factor (entering just following Job satisfaction) as an antecedent of intention to quit. However no similar significant impact was identified for performance. There may be an indirect path leading to performance, which is supported by the correlation data. All in all, the results strongly support hypothesis 3, and the model offered (see Figure 1 for the results). 


\section{Discussion and Conclusions}

The results reported in this study expand our understanding of the bullying phenomenon into the area of IT and computer mediated communication. The meaning of this for management in organizations is that bullying at work, while not a new phenomenon, can be found in novel media i.e. the e-mail. Moreover, the study indicates that such bullying results in similar negative effects as conventional bullying (cf. Adams, 1998). That should send an alarming signal to managers in organizations. The implications of the

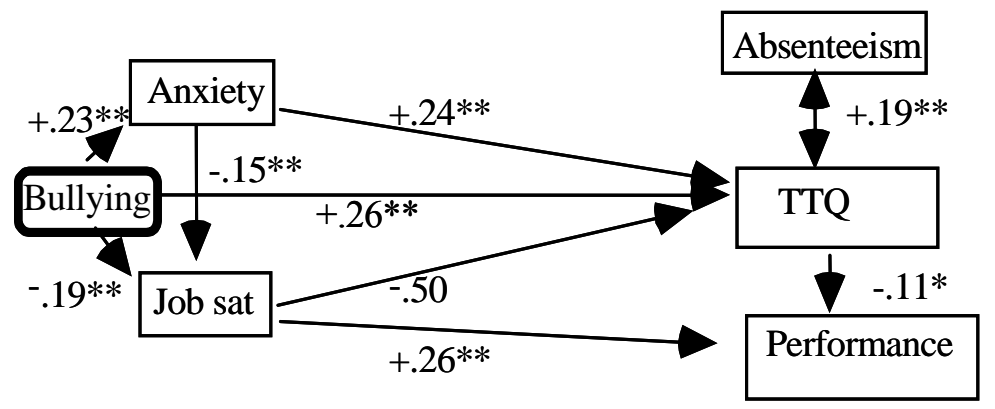

Figure 1. Analysis Results for the Research Model study are of great importance since the use of e-mail systems is on the increase. For some methods of flexible work and alternative work arrangements, e-mail is an essential part of communication, such as the case of telecommuting and the virtual organization (Baruch \& Nicholson, 1987; Davenport \& Pearlson, 1998; Standen, 2000). As for bullying impact on job attitudes and behaviors, H3 was fully supported, as indicated in the analysis and tables of results. Bullying in general and bullying on the e-mail in particular had strong negative impact, especially on work attitudes.

Among the possible reasons for the results of the present study are both the nature of e-mail communication and pressures that characterize the post-modern workplace. In addition, already known aspects of communication associated with IT correspondence gained further supporting evidence. Sproull and Kiesler (1986) have acknowledged the negative effect of electronic mediated communication on social context cues. Without the ability to transmit the latent elements of communication (such as body language), e-mail communication may opt or drift to more blunt expressions or cues that might be wrongly interpreted. Since the 'sender' cannot identify a case of the 'receiver' getting upset, such miscommunication cannot be rectified on the spot, leading to possible major misunderstanding and communication breaks.

The results of this study show clearly that the e-mail system, sought to be immune from hazards such as bullying, is just another medium through which bullying can occur. Due to its qualities and characteristics, the communication via e-mail can be easily misinterpreted. Moreover, it is a less personalized system, and its use might add to feeling of social isolation (Baruch, 2001). With increasing use and strong reliance upon IT communication, the e-mail, a useful and practical managerial tool might be transformed into an enabler of vicious behavior. Managers need to recognise the risks and apply safeguards where possible.

\section{Limitations and Suggestions for Future Research}

The contribution of this study should be considered in light of its limitations. One limitation is that it was conducted in one company only. Another is the typical problem of most surveys, i.e. partial response rate. Another limitation is the use of a single measure for the majority of the research population. However an argument for such use was presented earlier, and further test of comparing multiple item measures with the single ones for part of the population added to the validity of the measures.

Future research may develop means to tackle these limitations. It is important that further such studies are carried out. There are two major aspects, which the present study brings to the area of management studies. One is concerned with the environment of the study: the virtual organizations and IT communication are increasingly becoming subject for academic study, and rightfully so. The second relate to the specific topic under investigation - bullying. It shows that even new, up-to-date managerial tools are not immune from hazards of misuse and abuse. The outcomes of such improper use of IT should be thoroughly explored.

\section{References}

Adams, A. Bullying at Work. London: Virago. 1998.

Anderson, L. M. \& Pearson, C. M. Tit for tat? The spiralling effect of incivility in the workplace Academy of Management Review, 24/3, 1999, pp. 452-471.

Baruch, Y. The Autistic Society Information \& Management, 38/3, 2001, pp. 129-136.

Baruch, Y. \& Nicholson, N. Home, sweet work, Journal of General Management, 23/2, 1997, pp. 15-30.

Bhagat, R. S. Effects of stressful life events on individual performance effectiveness and work adjustment processes within organizational setting: A research model Academy of Management Review, 8/4, 1983, pp. 660-671. 
Clarke, J. Office Politics. London: The Industrial Society, 1999.

Davenport, T. H. \& Pearlson, K. Two cheers for the virtual office Sloan Management Review, 39/4, 1998, pp. 51-65.

Freud, S. On Psychopathology: Inhibitions, Symptoms and anxiety. Cited in The Pelican Freud Library. (Ed. A. Richards). Vol. 10 (1979), Middlesex: Penguin Books, 1926.

Gouldner, A. W. The norm of reciprocity: A preliminary statement American Sociological Review, 25, 1960, pp. 161-178.

Hallam, R. Counselling for anxiety problems. London: Sage Publications, 1992.

Joseph, R. Electronic mail and petty tyranny. In P. McCarthy, M. Sheehan, S. Wilkie, \& W. Wilkie, (Eds.) Bullying: Causes, Costs and Cures. Queensland: Beyond Bullying Association, 1998, pp. 115-131.

Mogensen, V. L. Office Politics: Computers, Labor, and the Fight for Safety and Health. New Brunswick, NJ: Rutgers University Press, 1996.

Neuman J.H. \& Baron R.A. Workplace violence and workplace aggression: evidence concerning specific forms, potential causes, and preferred targets, Journal of Management, 24, 1998, pp. 391-419.

Novell Shaming, Blaming and Flaming. a report by Ronin Research, Berkshire: Novell, 1998.

Sproull, L. \& Kiesler, S. Reducing social context cues: the case of electronic mail Management Science, 32, 1986, pp. $1492-1512$.

Standen, P. The home/work interface. In K. Daniels, D. A. Lamond, \& P. Standen, (Eds.) Managing Telework. London: Business Press, 2000, pp. 83-92.

Vardi, Y. \& Winer, Y. Misbehavior in organizations: A motivational framework Organization Science, 7, 1996, pp. 151-165.

Welch, J. Electronic menaces are a flaming liability People Management, 3/12, 1997, pp. 14. 